\title{
The digestion by cattle of grass silage made with formic acid and formic acid-formaldehyde
}

\author{
BY D. J. THOMPSON, D. E. BEEVER, C. R. LONSDALE*, \\ M. J. HAINES. S. B. CAMMELL AND A. R. AUSTIN \\ Grassland Research Institute, Hurley, Maidenhead, Berkshire SL6 SLR
}

(Received 18 July 1980-Accepted 11 November 1980)

\begin{abstract}
1. A primary growth crop of peren nial ryegrass (Lolium perenne L., cv. S23) was partially wilted and ensiled after the application of either formic acid-water $(1: 3, \mathrm{w} / \mathrm{v} ; 7 \cdot 1 \mathrm{l} / \mathrm{t}$ fresh herbage; control diet $\mathrm{C})$ or formic acid-formaldehyde $(1: 1, \mathrm{w} / \mathrm{w} ; 8.81 / \mathrm{t}$ fresh herbage; formaldehyde treated diet $\mathrm{F})$ which supplied $50 \mathrm{~g} \mathrm{HCHO} / \mathrm{kg}$ crude protein (nitrogen $(N) \times 6 \cdot 25)$. Thi: two silages were fed separately and a third diet comprising formaldehydetreated silage, supplemented with urea $(20 \mathrm{~g} / \mathrm{kg}$ dry matter DM) at the time of feeding was also examined (diet FU).

2. The three diets were fed at a leve! of $16 \mathrm{~g} \mathrm{DM} / \mathrm{kg}$ live weight to six 3- to six-month-old cattle fitted with rumen and re-entrant duodenal cannulcs in two $3 \times 3$ Latin Square experiments, and measurements were made of the digestion of energy, carbohydrate and $\mathrm{N}$.

3. The formaldehyde-treated silage had a lower content of fermentation acids and ammonia-N, and a higher content of water-soluble carbohydrate and total amino acids. The apparent digestibility of organic matter, energy and $N$ were depressed $(P<0.05, P<0.05$ and $P<0.01$ respectively) by treatment with formaldehyde, but cellulose and neutral-detergent fibre digestibility were unaffected.

4. Within the rumen the digestior. of organic matter, cellulose and neutral-detergent fibre were unaffected by formaldehyde treatment or supplem,ntation with urea. Microbial protein synthesis in the rumen was similar for the three diets (average $131 \mathrm{~g} / \mathrm{kg}$ apparently digested organic matter in the rumen).

5. The application of formic acid-formaldehyde increased $(P<0.05)$ the amount of food protein escaping degradation in the rumen (4.76 diet $\mathrm{C}, 6.89 \mathrm{diet} \mathrm{F} ; 7.07 \mathrm{diet} \mathrm{FU} \mathrm{g} / \mathrm{kg}$ protein intake). The contribution of amino acids of dietary origin at the duodenum increased $(P<0.05$ ) from 50 (diet $\mathrm{C}$ ) to 80 (diet F) and 82 (diet FU) $\mathrm{g} / \mathrm{kg} \mathrm{DM}$ intake, and the flow of total amino acids at the duodenum was $33 \%$ higher $(P<0.001)$ in cattle fed formic acid-formaldehyde silage diets compared with the control silage due to the reduction in degradation of protein at ensiling and in the rumen.
\end{abstract}

During silage fermentation, extensive proteolysis occurs with the final silage having a protein of high solubility whilst the non-protein-nitrogen can be as much as $60 \%$ of the total N. Formaldehyde has been used to protect protein from degradation in the rumen (Ferguson et al. 1967) and also as silage additive to reduce protein breakdown during ensiling (Wilkins et al. 19/4). The effect of formaldehyde on voluntary food intake (Wilkinson et al. 1976), digestibility (Barry, 1976a) and digestion (Beever et al. 1977; Siddons et al. 1979) of silage fed to sheep has previously been studied. In the present paper quantitative measurements were made of the digestion by cattle of the protein and energy in grass silage conserved with formic acid and with formic acid plus formaldehyde. In addition, a third diet comprising the formaldehyde-treated silage supplemented with urea at the time of feeding was studied, in order to examine what effect extra non-protein- $\mathrm{N}$ may have on microbial and total protein flow to the small intestine, should $\mathrm{N}$ supply to the microbes in the rumen be limited when formaldehyde-treated silage is fed (Beever $e t$ al. 1977).

\section{MATERIALS AND METHODS \\ Diets}

Primary-growth perennial ryegrass (Lolium perenne L., cv. S23) was cut with a rotary drum mower on 28 and $29 \mathrm{May}, 19 ; 4$, and within $2 \mathrm{~h}$ was harvested by means of a precision-chop forage harvester (chop length $60 \mathrm{~mm}$ ). At the time of harvesting the grass was treated with

- Present address: Kenneth Wilson Holdings Ltd. Morwick Hall. York Road, Leeds LSI5 4NB. 
either formic acid ( $850 \mathrm{~g}$ formic acid $/ \mathrm{kg}$ ), water $(1: 3 \mathrm{w} / \mathrm{v})$ at $7 \cdot 11 / \mathrm{t}$ fresh herbage (control; C), or formic acid - formalin $(350 \mathrm{~g}$ formaldehyde $/ \mathrm{kg})(1: 1, \mathrm{w} / \mathrm{v})$ at $8 \cdot 81 / \mathrm{t}$ fresh herbage (formaldehyde-treated; $F$ ). The two treated forages were subsequently ensiled in butyl-rubber bags, each bag containing approximately $15 \mathrm{t}$ fresh herbage, which were opened 11 months after the forage had been ensiled and preserved by freezing before feeding. The $F$ silage was supplemented at the time of feeding with urea $(20 \mathrm{~g} / \mathrm{kg}$ dry matter (DM)) and sodium sulphate $(210 \mathrm{~g} / \mathrm{kg}$ urea) and formed the third diet (FU).

\section{Animals}

Eight Friesian steer calves were weaned from milk at 5 weeks of age, given hay and concentrates for a further 5 weeks, when silage was incorporated as part of the diet. At 12 weeks of age, $40 \mathrm{~mm}$ diameter rubber rumen cannulas (Jarrett, 1948) and re-entrant cannulas (Ash, 1962; Brown et al. 1968) were inserted respectively in the rumen and into the proximal duodenum before the entry of the bile duct. At the beginning of the experiment the calves were approximately 14 weeks of age and weighed $130 \mathrm{~kg}$ (range 113-146 kg). By the end of the experiment the calves were approximately 32 weeks of age and weighed $152 \mathrm{~kg}$ (range 135-162 kg).

\section{Design: feeding and collection procedures}

Six of the calves were allocated at random to two $3 \times 3$ Latin Squares in a three-period crossover design, with an additional two calves being used initially to provide donor duodenal digesta for re-entry during duodenal collection periods. Due to the death of one animal and repeated blockage of the re-entrant cannula in the other animal their results were discarded and the two donor animals were substituted. The animals were weighed at the beginning of each $30 \mathrm{~d}$ experimental period and the diets were offered at a level of $16 \mathrm{~g} \mathrm{DM} / \mathrm{kg}$ live weight per $\mathrm{d}$ in two equal amounts at 09.30 and 16.30 hours, when $10 \mathrm{~g}$ chromic oxide-impregnated paper (Corbett et al. 1960) was inserted into the rumen immediately before feeding. Urea and $\mathrm{Na}_{2} \mathrm{SO}_{4}$ (treatment $\mathrm{FU}$ ) were mixed with the silage at feeding, in gradually increasing amounts over $14 \mathrm{~d}$ until a urea level equivalent to $2 \%$ of the DM offered was attained. Total faeces excreted over days 15-24 were collected by means of a light plastic tube (diameter $370 \mathrm{~mm}$ ) attached to a harness, whilst urine production over a $6 \mathrm{~d}$ period within days 15-24 was collected by pumping from a funnel beneath the animal into $\mathrm{M}$-sulphuric acid. Rumen samples for $\mathrm{pH}$, ammonia and volatile fatty acids (VFA) were removed hourly for $24 \mathrm{~h}$ from all calves within days 25-27. During days $27-30, \mathrm{Na}_{2}{ }^{35} \mathrm{SO}_{4}$ was infused into the rumen at a constant rate of $10 \mu \mathrm{Ci} / \mathrm{h}$ for a period of $40 \mathrm{~h}$ and a total collection of duodenal digesta was made during the last $24 \mathrm{~h}$ with the use of automatic-sampling equipment (Canaway $\&$ Thomson, 1977) as modified by Cammell (1977) for use with cattle. Representative samples of duodenal digesta were obtained automatically and unlabelled duodenal digesta previously collected from animals given the same diets were re-entered into the distal cannula at a rate similar to the outflow of digesta through the proximal cannula. One duodenal collection on treatment FU was incomplete due to blockage in the cannula.

\section{Preparation of samples}

Representative samples of the herbage were obtained at the time of cutting and stored frozen before botanical separation, and representative samples of the harvested herbage were obtained ai the time of ensiling and prepared for chemical analysis by freeze-drying and subsequent grinding through a small laboratory mill. Representative samples of the two silages were obtained during each experimental period and used for analysis either in the fresh state or freeze-dried and ground before analysis. All duodenal digesta samples were 
freeze-dried and ground betore analysis, and accumulated faecal samples $(10 \%$ of daily production) were either used in the fresh state or freeze-dried and ground. Daily urine output was measured for each calf and representative samples $(10 \%$ of daily production) stored frozen before analysis in the liquid state. All rumen fluid samples for ammonia and VFA analysis were centrifuged a: $2500 \mathrm{rev}$. $/$ min for $5 \mathrm{~min}$, acidified with $\mathrm{M}^{-} \mathrm{H}_{2} \mathrm{SO}_{4}$ and then bulked ( $4 \mathrm{~h}$ periods) for each animal.

\section{Analytical techniques}

The fresh samples of silage were used to determine the contents of DM by toluene distillation (Dewar \& McDonald, 1961), total N (macro Kjedahl), volatile acids, methanol and ethanol (Wilson \& Wilkins, 1972) and lactic acid (Elsden \& Gibson, 1954). For all other silage analyses, freeze-dried material was used. Soluble $\mathbf{N}$ content of the silages was determined using $0.1 \mathrm{~g}$ pepsin/l M-hydrochloric acid for $16 \mathrm{~h}$ (Beever et al. 1976). The contents of organic matter (OM), cellulose, individual amino acids of the silage, duodenal digesta and faecal samples were determined using previously-described techniques (Beever $e t$ al. 1977), and the neutral-(NDF) and acid-detergent (ADF) fibre fractions of these samples were determined using the procedures of Van Soest \& Wine (1967). The gross energy (GE) value of the two silages was determined on fresh material in an adiabatic bomb calorimeter (Grassland Research Institute, 1961) and the values were corrected for the content of the volatile fractions as outlinec by Terry \& Osbourn (1980). In vitro DM digestibility of the fresh herbage was determined by the method of Tilley \& Terry (1963) and the water-soluble carbohydrate content of the silages was determined using the automated ferricyanide technique (Technicon N9b) "ollowing cold-water extraction and acid-hydrolysis.

The VFA concentrations of rumen fluid were determined by gas-liquid chromatography using the techniques described by Thomson et al. (1978), whilst ammonia concentrations were determined by autoanalyzer (Technicon N3a) using alkaline phenol. The specific activities of microbial and duodenal protein were determined using the techniques described by Beever et al. (1974).

$\mathrm{Cr}_{2} \mathrm{O}_{3}$ concentrations of all duodenal digesta and faecal samples and the administered $\mathrm{Cr}_{2} \mathrm{O}_{3}$-impregnated paper were determined by the method of Christian \& Coup (1954).

\section{Calculation of results and statistical analysis}

The flow of DM to the duodenum was calculated using the $\mathrm{Cr}_{2} \mathrm{O}_{3}$ concentration in the duodenal digesta (MacRae d' Armstrong, 1969) and the flow of individual nutrients was subsequently calculated from a knowledge of individual nutrient concentration. The concentrations of hemicellulose in food, duodenal digesta and faeces were calculated as NDF minus ADF, after appropriate corrections for $\mathrm{N}$ contamination had been taken into account (R. A. Terry, personial communication).

Missing samples amounted to one duodenal sample (diet FU) and one urine sample (diet F). Consequently, missing values were fitted according to the techniques described by Snedecor (1956). Analyses of variance were performed on the values removing period, animal and diet effects, and the standard errors are presented for full replication.

\section{RESULTS}

The botanical and chemical compositions of the herbage as harvested are given in Table 1, indicating that perennial ryegrass (cv. S23) comprised $75 \%$ of the dry weight of the crop. The remainder were made up of approximately equal amounts of other grass species, weeds and dead material. At the time of harvest the forage contained $25 \mathrm{~g} \mathrm{~N} / \mathrm{kg}$ at an estimated digestibility value of $0 \cdot 72$.

The chemical compositior of the resulting silages is given in Table 2, indicating no 
Table 1. Botanical and chemical composition of the forage harvested before ensiling

\begin{tabular}{|c|c|}
\hline & Cut grass \\
\hline \multicolumn{2}{|c|}{ Botanical (g DM/kg DM) } \\
\hline $\begin{array}{l}\text { Perennial ryegr } \\
\text { Leaf } \\
\text { Stem } \\
\text { Other grasses } \\
\text { Other species } \\
\text { Dead material }\end{array}$ & $\begin{array}{r}423 \\
330 \\
93 \\
82 \\
72\end{array}$ \\
\hline \multicolumn{2}{|c|}{ Chemical (g/kg DM) } \\
\hline $\begin{array}{l}\mathrm{DM}(\mathrm{g} / \mathrm{kg}) \\
\text { Organic matter } \\
\text { Total nitrogen } \\
\text { Soluble } \mathrm{N} \\
\mathrm{D} \text { value }\end{array}$ & $\begin{array}{c}202 \cdot 0 \\
911 \cdot 5 \\
25 \cdot 4 \\
1 \cdot 85 \\
0.72\end{array}$ \\
\hline
\end{tabular}

DM, dry matter; $\mathrm{D}$, in vitro digestibility of organic matter in the dry matter.

Table 2. Chemical composition ( $\mathrm{g} / \mathrm{kg}$ dry matter (DM)) of the control (C) and formaldehyde-treated $(F)$ silages

\begin{tabular}{lcc}
\hline Silage & C & F \\
\hline Toluene DM & 211 & 211 \\
Organic matter & 916 & 917 \\
Gross energy (MJ/kg DM) & $18 \cdot 7$ & 19.0 \\
Water-soluble carbohydrate & 9.8 & 124 \\
Cellulose & 243 & 254 \\
Neutral-detergent fibre* & 487 & 459 \\
Acid-detergent fibre* & 317 & 304 \\
Total nitrogen & 26.4 & 26.7 \\
Soluble N & $12 \cdot 2$ & 13.2 \\
Ammonia N & 2.6 & Trace \\
Total amino acids & 101 & 112.7 \\
Fermentation products & & \\
Acetic acid & 34.0 & 8.0 \\
Propionic acid & 1.9 & 1.5 \\
Butyric acid & 2.1 & 1.8 \\
Lactic acid & 157 & 15.6 \\
Methanol & 1.0 & 1.7 \\
Ethanol & 3.6 & 4.6 \\
Total acids & 195 & 26.9 \\
pH & 3.93 & 4.50 \\
\hline \hline
\end{tabular}

* According to Van Soest \& Wine (1967).

differences in the contents of toluene DM, organic matter (OM), gross energy, NDF and ADF and total and soluble $\mathrm{N}$. Total amino acid and water-soluble carbohydrate contents of the treated silage $(112 \cdot 7,124 \cdot 2 \mathrm{~g} / \mathrm{kg}$ DM respectively) were higher than those in the central silage $(101 \cdot 4,9 \cdot 8 \mathrm{~g} / \mathrm{kg}$ DM respectively). Conversely, the concentrations of fermentation acids, in particular lactic acid, were substantially lower (diet F, $2 \cdot 7$, diet C, $19.5 \mathrm{~g} / \mathrm{kg} \mathrm{DM}$ ) and the pH higher (diet F, 4.5 diet $\mathrm{C}, 3.9$ ) in the treated compared with the control silage. The concentrations of methanol and ethanol both appeared to be higher in the treated silage. 


\section{Digestion of organic matter, gross energy and carbohydrates}

The intake, flow into the small intestine and excretion in the faeces of the OM and GE fractions are given in Table 3. In addition, the daily quantities of energy present in the urine are presented. The dietary treatments had no effect on the amounts of $O M$ and GE present in the duodenum or in the faeces but over-all digestibilities of the two formaldehyde diets (F and FU) were significantly $(P<0.05)$ lower than $\operatorname{diet} \mathrm{C}(\mathrm{OM}$ : $\operatorname{diet} \mathrm{C}, 76 \cdot 4$, diets $\mathrm{F}$ and FU, 73.9; GE: diet C, 73.2, diets F and FU 70.0). Expressing the extent of rumen digestion of energy as a fraction of total digestion occurring in the whole tract, indicated a slight reduction on the treated silage diet (diet $\mathrm{C}, 0.66$, diet $\mathrm{F}, 0.60$ ) and supplementation with urea gave a value of 0.65 . A similar trend for OM digestion was observed $(0.73,0.69$ and 0.71 respectively). Urinary energy excretion was reduced by $15 \%$ on diets $F$ and FU compared with diet $C(P<0.05)$, when adjusted to a mean energy intake of $47 \mathrm{MJ} / \mathrm{d}$.

The results for the digestion of carbohydrate fractions are shown in Table 4. Values for the digestion of water-solvble carbohydrate (not presented) indicated virtually complete digestion within the reticulo-rumen, amounting to 18,320 and $270 \mathrm{~g} / \mathrm{d}$ for diets $\mathrm{C}, \mathrm{F}$ and FU respectively (diets F and FU v. diet C, $P<0.001$ ).

Neither the addition of formaldehyde nor supplementation with urea affected cellulose digestibility, and the quantity of cellulose digested in the reticulo-rumen exceeded $96 \%$ of the total amount digested. Similar results were observed for the digestion of the hemicellulose fraction.

Changes in the mean molar percentages of acetic, propionic and butyric acid in the rumen fluid with time within the day are illustrated in Fig. 1 . The molar percentage of acetate was lower $(P<0.05)$, and propionate $(P>0.05)$ and butyrate higher $(P<0.05)$ in the rumen fluid of calves fed diet $C$ cornpared with diets $F$ and $F U$ which were similar. The differences were most apparent immediately after feeding, but were minimal by $8 \mathrm{~h}$ after the afternoon feed.

\section{The flow, absorption and utilization of nitrogenous components}

To aid interpretation, results for the flow and absorption of $\mathrm{N}$ and amino acids have been expressed per $\mathrm{kg}$ DM consurned, in contrast to previous values which refiected differences in the quantities of DM (mean values $2.52,2.64$ and $2.30 \mathrm{~kg} / 24 \mathrm{~h}$ respectively) and nutrients consumed according to variations in animal weight throughout the experiment. Similarly for the $\mathrm{N}$ retention values, the results are expressed per $\mathrm{kg} \mathrm{N}$ consumed. These reults are presented in Table 5.

Supplementation of the formic acid-formaldehyde-treated silage with urea did not increase the flow of $\mathbf{N}$ at the duodenum compared with diet $\mathrm{F}$. Both of these diets, however, showed significantly $(P<0.01)$ higher flows than the diet $\mathrm{C}$, but in comparison with $\mathrm{N}$ intake, only diet $\mathrm{F}$ showed a net increase in $\mathrm{N}$ across the reticulo-rumen. The amounts of $\mathrm{N}$ present in the faeces of calves given diets $\mathrm{F}$ and $\mathrm{FU}$ were higher $(P<0.05)$ than that recorded for diet $\mathbf{C}$, and consequently apparent $\mathbf{N}$ digestibility was depressed on diet $\mathbf{F}$ compared with diet $\mathrm{C}(P<0.01)$; the value for total $\mathrm{N}$ in the faeces on diet $\mathrm{FU}$ was intermediate between the two unsupplemented diets.

On the assumption that the added urea- $\mathrm{N}$ was totally digested, it would appear that apparent digestibility of the silage $\mathrm{N}$ of diet $\mathrm{FU}$ was of the order of 0.59 , indicating a small increase compared with the insupplemented formaldehyde-treated silage (diet F). Despite these changes, the availability of duodenal $\mathrm{N}$ within the hindgut ranged between 0.63 and 0.65 , and was unaffected by the dietary treatments imposed.

Formaldehyde treatment significantly $(P<0.01)$ reduced the quantity of $\mathrm{N}$ present in the urine, compared with diet $\mathbf{C}$ and the addition of urea- $\mathrm{N}$ to diet $\mathrm{F}$ resulted in an increase 
D. J. THOMPSON AND OTHERS

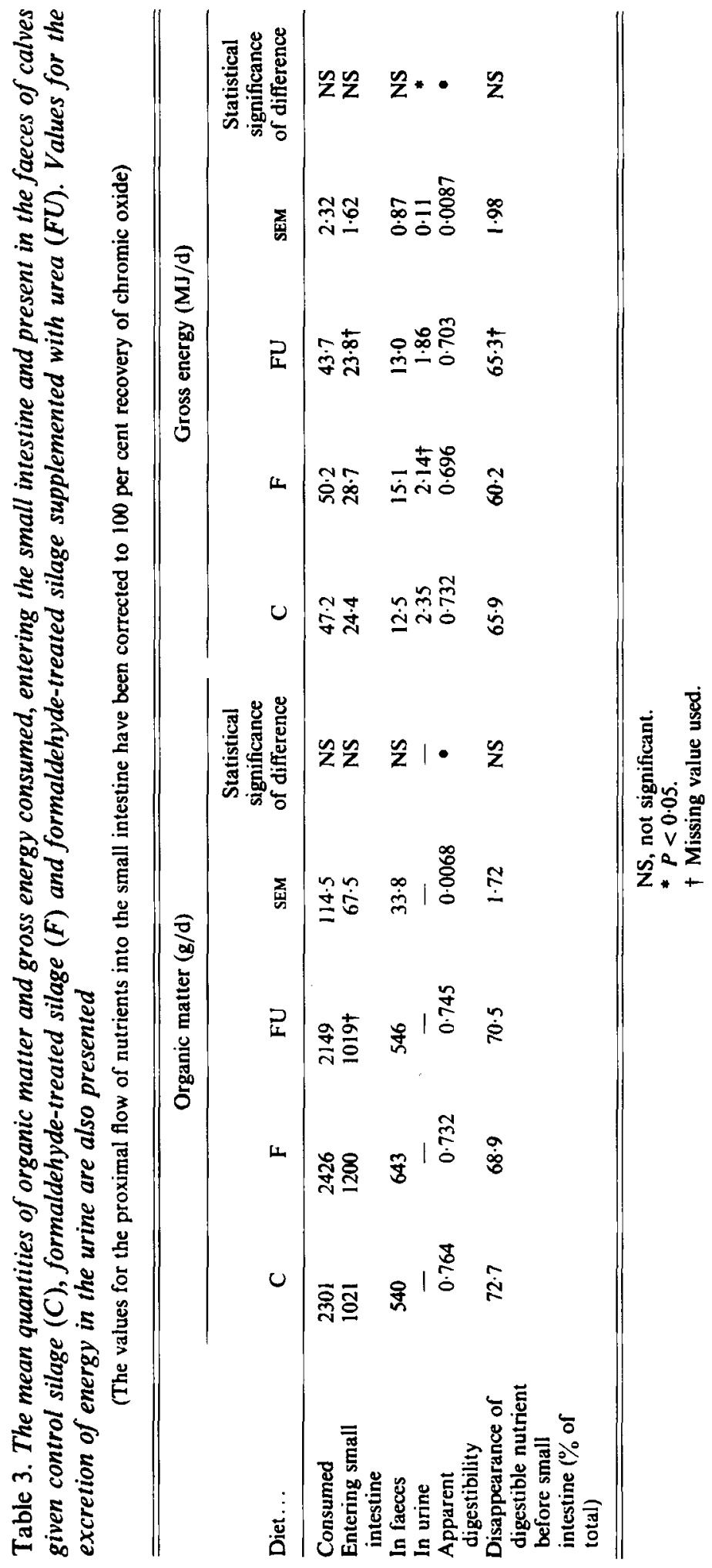




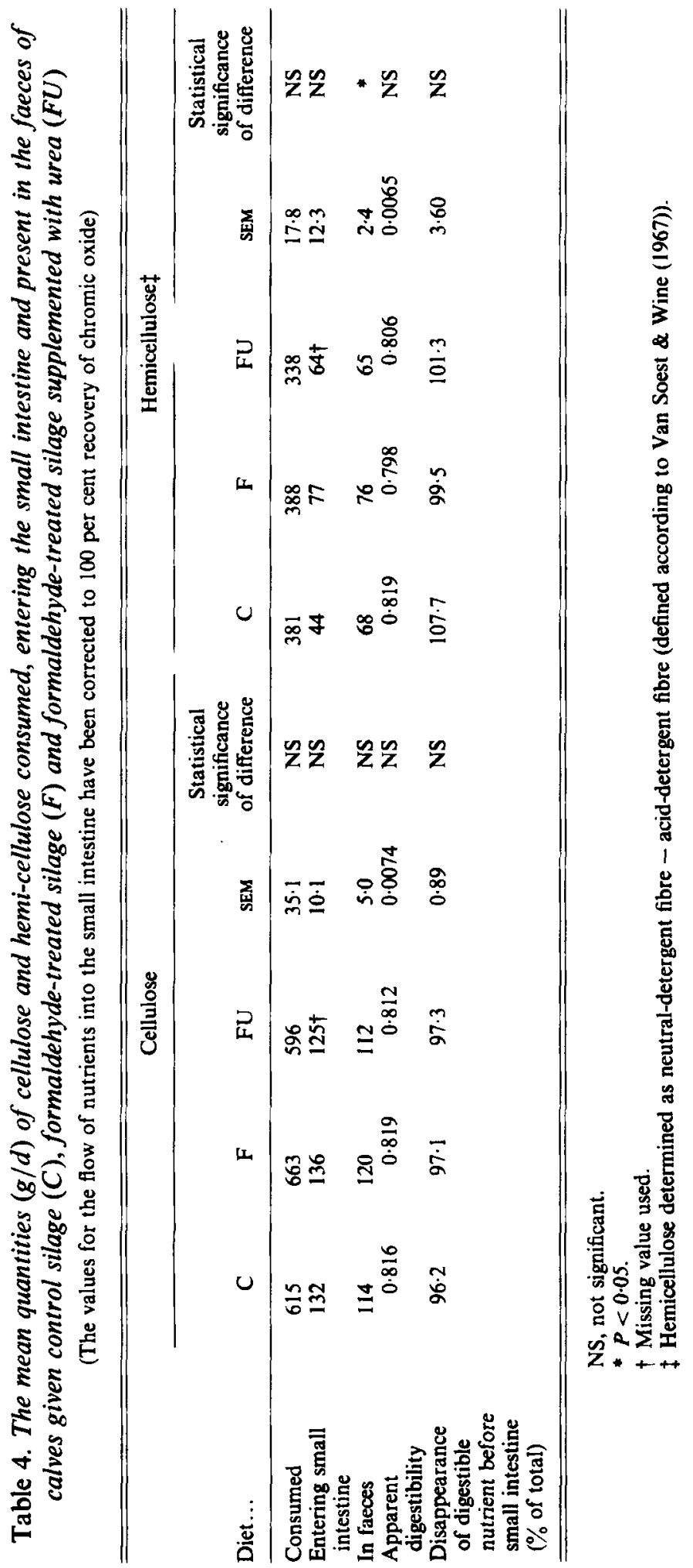




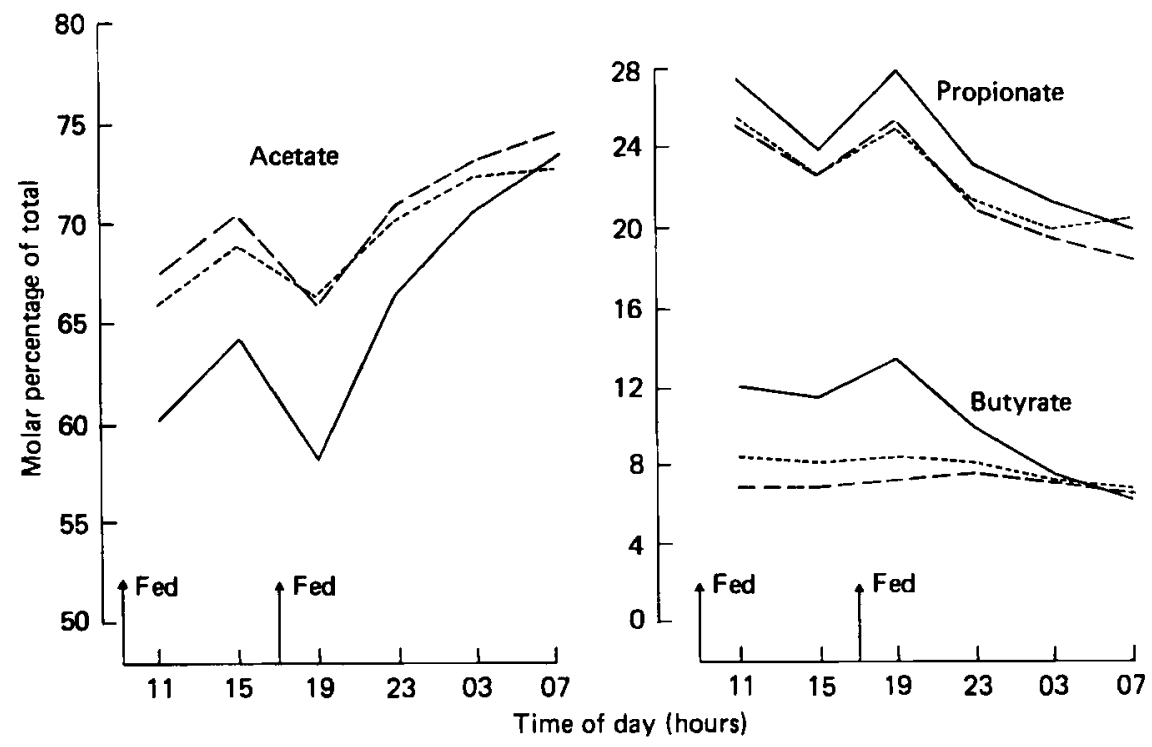

Fig. 1. Daily variations in the molar percentage of volatile fatty acids in the rumen of calves given the control $(-)$, formaldehyde-treated $(-\ldots$,$) ) and formaldehyde-treated +$ urea $(---)$ silage diets.

Table 5. The mean quantities of nitrogen $(g / 24 h)$ present in the food, faeces and urine and entering the small intestine of calves given the control silage $(C)$, formaldehyde-treated silage $(F)$ and the formaldehyde-treated silage supplemented with urea $(F U)$

(The values for the proximal duodenum and in the faeces have been corrected to 100 per cent recovery of chromic oxide)

\begin{tabular}{|c|c|c|c|c|c|}
\hline Diet... & C & $\mathbf{F}$ & FU & SEM & $\begin{array}{l}\text { Statistical } \\
\text { significance } \\
\text { of difference }\end{array}$ \\
\hline \multicolumn{6}{|c|}{ Total N present (g N/kg DMI) } \\
\hline In food & $26 \cdot 40$ & $26 \cdot 70$ & 35.74 & 0.016 & **** \\
\hline $\begin{array}{l}\text { Entering proximal } \\
\text { duodenum }\end{array}$ & $24 \cdot 63$ & $31 \cdot 75$ & $32 \cdot 38 \dagger$ & 1.013 & $* *$ \\
\hline In urine & 11.92 & $8.69 \dagger$ & 15.45 & 0.473 & $* * *$ \\
\hline In faeces & 8.82 & 11.86 & 10.89 & 0.637 & * \\
\hline $\mathrm{N}$ balance & 5.66 & $6.40 \dagger$ & 9.40 & 0.498 & ** \\
\hline Apparent digestibility of $\mathbf{N}$ & 0.666 & 0.555 & 0.695 & 0.215 & ** \\
\hline $\mathrm{N}$ balance ( $\mathrm{g} / \mathrm{kg} \mathrm{N}$ intake) & $2 \cdot 14$ & $2 \cdot 43$ & $2 \cdot 63$ & 0.181 & NS \\
\hline
\end{tabular}

DMI, dry matter intake; NS, not significant.

$* P<0.05, * * P<0.01, * * * P<0.001$.

+ Missing values used.

of $6.8 \mathrm{~g}$ of urinary $\mathrm{N} / \mathrm{kg}$ DM intake (diet $\mathrm{FU} v$. diet $\mathrm{F},(P<0.001)$ equivalent to approximately $75 \%$ of the nitrogen contained in the urea supplement.

$\mathrm{N}$ balance, expressed as $\mathrm{g} \mathrm{N}$ retained per $\mathrm{kg}$ DM diet consumed, was not affected by formaldehyde treatment, but the addition of urea elevated the mean value from 6.0 to $9.4 \mathrm{~g} / \mathrm{d}(P<0.01)$, indicating an apparent efficiency of urea- $\mathrm{N}$ utilization of approximately $33 \%$ of the total supplied. The dietary mean values for $\mathrm{N}$ retention expressed as a percentage of total N consumed (diet C 21, diet F 24, diet FU 26) were not significantly different. 


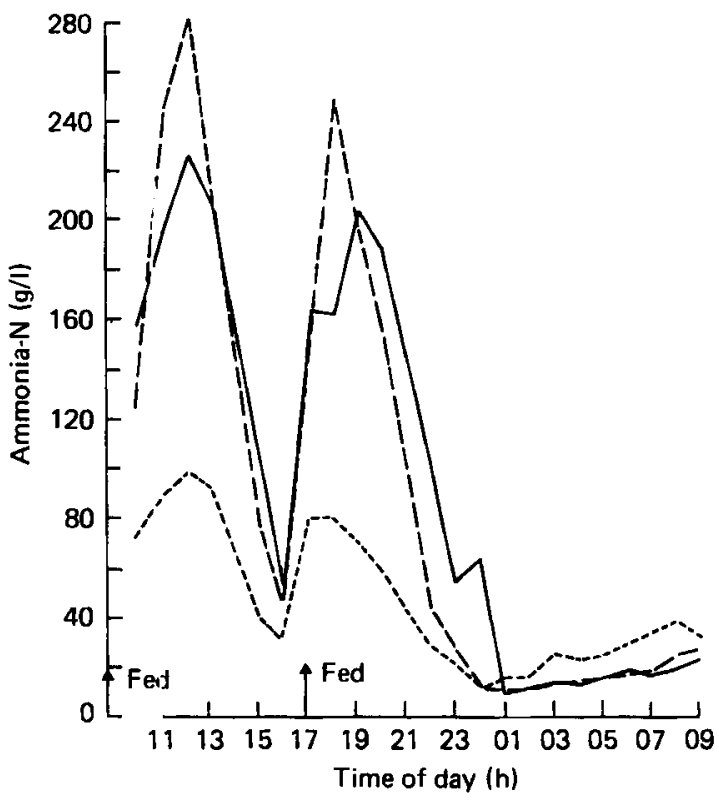

Fig. 2. Daily variations in the rumen ammonia nitrogen concentration $(\mathrm{g} / \mathrm{l})$ of calves given the control (-), formaldehyde-treated (- - - $\left.^{-}\right)$and formaldehyde-treated + urea (- - ) silage diets.

The changes in rumen ammonia concentration in relation to feeding are illustrated in Fig. 2 and show diet $C$ with typical peaks of ammonia concentration of $210-230 \mathrm{mg}$ ammonia-N/1 at $2-3 \mathrm{~h}$ post feeding. Formaldehyde treatment significantly reduced these peaks to 100 and $80 \mathrm{mg}$ ammonia- $\mathrm{N} / 1$, and the addition of urea increased the levels of rumen ammonia to values higher than those recorded with diet $\mathrm{C}$. Consequently, the values obtained on diet $F$ were significantly $(P<0.05)$ lower than those recorded on the other two diets.

The intake, duodenal flow and faecal excretion of individual and total amino acids (TAA) expressed as $\mathrm{g} / \mathrm{kg}$ DM ingested, are illustrated in Table 6.

Intake of TAA was similar on all three diets and for each diet more TAA entered the small intestine than was consiumed. However, the flow of TAA to the duodenum of cattle given the two formaldehyde diets (diets F and FU) was significantly $(P<0.001)$ greater than that observed on diet $C$. Faecal excretion on diet $F$ was higher $(P<0.01)$ than on diet $\mathrm{C}$, and the amount excreted on diet FU was intermediate between the other two diets and not different from either $(P>0.05)$. Both diets $F$ and $F U$ showed a significant $(P<0.01)$ increase in the cuantity of TAA absorbed post duodenum compared with diet $C(118 v .87 \mathrm{~g} / \mathrm{d})$ whilst apparent availability of TAA entering the small intestine was unaffected by the treatments imposed (mean 0.73 ).

There was a net loss of proline between mouth and duodenum on both diets $\mathrm{C}$ and $\mathrm{F}$, and of leucine and alanine on diet $\mathrm{C}$ only. Net gains were recorded for all other amino acids and in the instance of lysine, isoleucine, histidine and threonine on the two formaldehyde diets, and tyrosine on all diets, these increases were quite considerable. In relation to absorption of the individual amino acids, diets F and FU behaved similarly, and in comparison with diet $\mathrm{C}$, absorption on the two formaldehyde diets was $14 \%$ higher for lysine, representing the smallest increase; most other amino acids showed increases of the order of 25 (tyrosine) $-47 \%$ (phenylalanine).

Examination of the composition of the absorbed amino acid fraction (see Fig. 3) indicated 
Table 6. The mean quantities of individual and total amino acids $(\mathrm{g} / \mathrm{kg}$ dry matter) present in the food, entering the duodenum and excreted in the faeces of calves given control silage $(C)$, formaldehyde-treated silage $(F)$ and formaldehyde-treated silage supplemented with urea $(F U)$

(The values at the duodenum and in the faeces have been corrected for 100 per cent recovery of chromic oxide)

\begin{tabular}{|c|c|c|c|c|c|c|c|c|c|c|}
\hline \multirow[b]{2}{*}{ Diet... } & \multicolumn{2}{|c|}{ In food } & \multicolumn{4}{|c|}{ At duodenum* } & \multicolumn{4}{|c|}{ In faeces } \\
\hline & C & $\begin{array}{c}F \text { and } \\
F U\end{array}$ & C & $\mathbf{F}$ & FU & SEM & $\mathrm{C}$ & $\mathbf{F}$ & FU & SEM \\
\hline Histidine & 2.6 & $2 \cdot 1$ & $2 \cdot 9$ & 3.8 & 3.8 & 0.12 & $0 \cdot 8$ & 1.0 & 0.9 & 0.07 \\
\hline Isoleucine & $6 \cdot 2$ & $6 \cdot 0$ & $8-3$ & $10 \cdot 6$ & $10 \cdot 3$ & 0.34 & $2 \cdot 3$ & $2 \cdot 8$ & $2 \cdot 6$ & 0.11 \\
\hline Leucine & $10 \cdot 2$ & $10 \cdot 8$ & $10 \cdot 0$ & 13.6 & $13 \cdot 8$ & 0.53 & 3.0 & $3 \cdot 7$ & $3 \cdot 2$ & 0.13 \\
\hline Lysine & $6 \cdot 8$ & $3 \cdot 6$ & $8 \cdot 3$ & $9 \cdot 7$ & $9 \cdot 7$ & 0.28 & 1.8 & $2 \cdot 3$ & $2 \cdot 1$ & $0 \cdot 12$ \\
\hline Phenylalanine & $5 \cdot 5$ & $7 \cdot 1$ & $7 \cdot 1$ & $9 \cdot 8$ & $9 \cdot 7$ & 0.31 & $2 \cdot 2$ & $2 \cdot 7$ & $2 \cdot 4$ & 0.11 \\
\hline Threonine & $5 \cdot 0$ & $5 \cdot 4$ & $6 \cdot 7$ & $8 \cdot 7$ & $8 \cdot 6$ & 0.29 & 1.9 & $2 \cdot 4$ & $2 \cdot 1$ & 0.08 \\
\hline Tyrosine & $2 \cdot 2$ & $4 \cdot 1$ & $5 \cdot 4$ & $6 \cdot 7$ & 6.5 & 0.22 & 1.4 & 1.6 & $1 \cdot 5$ & 0.06 \\
\hline Valine & $7 \cdot 3$ & $7 \cdot 3$ & $8 \cdot 5$ & $11 \cdot 4$ & $11 \cdot 3$ & 0.36 & $2 \cdot 5$ & $3 \cdot 1$ & 2.8 & 0.20 \\
\hline Alanine & $10 \cdot 5$ & $8 \cdot 3$ & $8 \cdot 8$ & $11 \cdot 4$ & 11.4 & 0.54 & $2 \cdot 5$ & $3 \cdot 1$ & 2.7 & 0.12 \\
\hline Arginine & $2 \cdot 8$ & $6 \cdot 6$ & $5 \cdot 8$ & 8.6 & $8 \cdot 5$ & 0.37 & $1 \cdot 5$ & 1.9 & 1.6 & 0.07 \\
\hline Aspartic acid & $10 \cdot 3$ & $13 \cdot 0$ & $13 \cdot 0$ & $17 \cdot 5$ & $17 \cdot 1$ & 0.60 & $3 \cdot 3$ & $4 \cdot 6$ & $4 \cdot 0$ & $1 \cdot 19$ \\
\hline Glutamic acid & $13 \cdot 4$ & $18 \cdot 1$ & $15 \cdot 8$ & $22 \cdot 1$ & $21 \cdot 7$ & 0.73 & $4 \cdot 8$ & 6.7 & $5 \cdot 6$ & 0.41 \\
\hline Glycine & $6 \cdot 7$ & $7 \cdot 4$ & $8 \cdot 7$ & $11 \cdot 2$ & $11 \cdot 2$ & 0.42 & $2 \cdot 5$ & $3 \cdot 2$ & $2 \cdot 8$ & 0.15 \\
\hline Proline & $7 \cdot 2$ & $7 \cdot 4$ & $5 \cdot 4$ & $7 \cdot 2$ & $7 \cdot 8$ & 0.37 & $1 \cdot 7$ & $2 \cdot 2$ & $1 \cdot 9$ & 0.11 \\
\hline Serine & $5 \cdot 5$ & $5 \cdot 7$ & $6 \cdot 2$ & $8 \cdot 1$ & 7.9 & 0.28 & 1.7 & $2 \cdot 2$ & $1 \cdot 8$ & 0.07 \\
\hline Methionine & $2 \cdot 6$ & $3: 5$ & $2 \cdot 5$ & $3 \cdot 4$ & $3 \cdot 3$ & 0.07 & 0.8 & $1 \cdot 2$ & $1 \cdot 4$ & \\
\hline Total & $104 \cdot 6$ & $116 \cdot 2$ & $123 \cdot 3$ & 163.8 & $161 \cdot 8$ & $4 \cdot 81$ & $34 \cdot 8$ & $44 \cdot 5$ & $39 \cdot 3$ & 1.91 \\
\hline
\end{tabular}

* Missing value used.

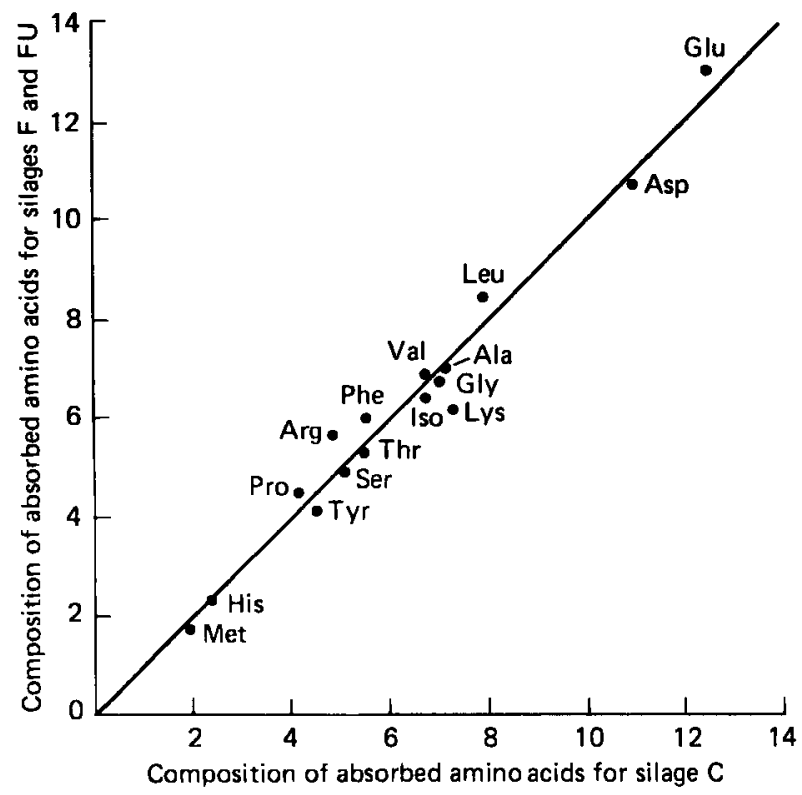

Fig. 3. Relationship between the composition ( $\%$ ) of the post-rumen absorbed amino acids of calves given control silage $(C)$ and the mean value of the formaldehyde-treated silage $(F)$ and formaldehyde-treated silage supplemented with urea (FU). 
Table 7. The composition of the amino acids entering the small intestine $(\mathrm{g} / \mathrm{kg}$ dry matter intake) and the efficiency of microbial protein synthesis in the rumen of calves given control silage $(C)$, formaldehyde-triated silage $(F)$ and formaldehyde-treated silage supplemented with urea $(F U)$

\begin{tabular}{|c|c|c|c|c|c|}
\hline Diet... & $\mathrm{C}$ & $F$ & FU & SEM & $\begin{array}{l}\text { Statistical } \\
\text { significance } \\
\text { of difference }\end{array}$ \\
\hline \multicolumn{6}{|l|}{$\begin{array}{l}\text { Quantity of amino acids } \\
\text { entering small intestine: }\end{array}$} \\
\hline $\begin{array}{l}\text { Total } \\
\text { Microbial }\end{array}$ & 123 & 164 & 162 & $4 \cdot 8$ & *** \\
\hline $\begin{array}{l}\text { Microbial } \\
\text { Food }\end{array}$ & 60 & $\begin{array}{l}66 \\
80\end{array}$ & 62 & $7 \cdot 6$ & NS \\
\hline \multicolumn{6}{|l|}{$\begin{array}{l}\text { Efficiency of microbial protein } \\
\text { synthesis: }\end{array}$} \\
\hline $\begin{array}{l}\text { g/kg rumen digested organic matter } \\
\% \text { Undegraded food protein entering } \\
\text { small intestine }\end{array}$ & $\begin{array}{c}119 \\
47.6\end{array}$ & $\begin{array}{c}148 \\
68.9\end{array}$ & $\begin{array}{l}127 \\
70 \cdot 7\end{array}$ & $\begin{array}{c}16.7 \\
5.41\end{array}$ & NS \\
\hline
\end{tabular}

NS, not significant.

- $P<0.05,{ }^{* * *} P<0.001$ (assumes $11 \%$ of total protein flowing to small intestine is of endogenous origin).

that formaldehyde treatment, with or without the addition of urea, reduced lysine and tyrosine contents $(P<0.01)$ and increased phenylalanine and arginine contents $(P<0.01$ and $P<0.05$ respectively)

The origin of the amino acids entering the duodenum, in terms of synthesized microbial protein and undegraded food protein, along with estimates of the efficiency of microbial protein synthesis, are given in Table 7. Microbial protein, per $\mathrm{kg}$ DM consumed, amounted to $60 \mathrm{~g} / \mathrm{d}$ on diet $\mathrm{C}$, and this was not affected by either formaldehyde treatment or the addition of urea. The quantities of undegraded food protein ( $\mathrm{g} / \mathrm{kg}$ DM intake) entering the small intestine were estimated to be considerably higher $(P<0.05)$ for diets $F(80)$ and $\mathrm{FU}(82)$ than for diet $\mathrm{C}(50)$. The ingested dietary protein undegraded in the rumen increased $(P<0.05)$ from 0.476 (diet $C)$ to 0.689 (diet F) and 0.707 (diet FU) and degradability declined as a result of the ajplication of formaldehyde from $0.522(\operatorname{diet} \mathrm{C}$ ) to a mean value of 0.303 (diet F 0.312, diet FU 0.294).

Efficiency of microbial protein synthesis averaged $131 \mathrm{~g} / \mathrm{kg}$ apparently-digested organic matter in the reticulo-rumen with a range of values from 119 to $148 \mathrm{~g} / \mathrm{kg}$ : none of the differences was found to be statistically significant.

\section{DISCUSSION}

Despite the addition of formic acid before ensiling, the control silage had appreciable levels of organic acids resembling those reported by Beever et al. (1977) for a direct-cut silage made without additive trea:ment from perennial ryegrass cut at a similar stage of growth. As expected, the application of formic acid-formaldehyde gave rise to a silage of lower organic acid and higher water-soluble carbohydrate contents, confirming the findings of Wilkins et al. (1974), Beever et al. (1977) and Siddons et al. (1979). The silage produced under conditions of restricted fermentation had $\mathbf{4 0} \%$ more alcohols as methanol and ethanol than diet $\mathbf{C}$.

The over-all effects of forraldehyde treatment on nutrient digestion within and absorption from the alimentary tract of cattle appear, at least in gross terms, to be similar to those recorded by Beever et al. (1977) for sheep. The flow of amino acids to the small intestine 
was elevated by $33 \%$ compared with diet $\mathrm{C}$, and over $70 \%$ of this increase was found to be due to the passage of more undegraded dietary protein out of the rumen. Values for the small intestinal absorption of amino acids were not available from this study, but on the basis of values obtained for amino acid disappearance in the whole hind-gut (cattle and sheep) in relation to disappearance from the small intestine (sheep) it would appear that, as in the earlier study, the application of formaldehyde to direct-cut grass before ensiling could enhance amino acid supply to the host tissues by approximately $15-25 \%$.

The study of Siddons et al. (1979) reports responses to formaldehyde application in the same direction as those obtained in this study, but of considerably greater magnitude. Thus, compared with the control silage, formaldehyde increased amino acid flow into and absorption from the small intestine by 69 and $80 \%$. However, both grasses were wilted to $260 \mathrm{~g} \mathrm{DM} / \mathrm{kg}$ before ensiling and in a recent review, Beever (1980) has drawn attention to the reduced protein supply on wilted compared with direct-cut silages.

One important difference to emerge from the three digestion studies already cited is that when Beever et al. (1977) used $60 \mathrm{~g}$ formaldehyde/ $\mathrm{kg}$ crude protein in the diet, microbial protein synthesis was markedly reduced, but in this study ( $50 \mathrm{~g}$ formaldehyde $/ \mathrm{kg}$ ) and that of Siddons et al. (1979) (35 g formaldehyde/ $\mathrm{kg}$ ) no depressions were noted. With such limited information it is difficult to recommend a desirable level of formaldehyde application, but until other studies are conducted, the recommendation of Barry (1976b) of 35-45 $\mathrm{g}$ formaldehyde $/ \mathrm{kg}$ appears appropriate.

As in the two previous studies, there was no indication of a reduction in the extent of rumen digestion of structural carbohydrates as a result of formaldehyde treatment. Rumen ammonia concentrations were reduced on the treated diet compared with the control diet (as in the two studies cited above) and it would appear that, at the restricted levels of feeding adopted, the reduction in ammonia availability was not sufficient to depress the extent of carbohydrate fermentation. The addition of urea to the formalin silage had in the present study no effect on either net microbial protein synthesis or extent of fibre digestion in the rumen, but there was an approximately three-fold increase in post-feeding ammonia concentrations.

The higher water-soluble carbohydrate content of the treated diet led to significantly more total carbohydrate (water-soluble + cellulose and hemicellulose) being digested in the rumen on diets F and FU (diet C 336, diet F 440, diet FU $442 \mathrm{~g} / \mathrm{kg}$ DM intake) with the more-readily-available source representing $3 \cdot 3$ and $28 \%$ of the total carbohydrates respectively. Higher levels of propionic acid in the rumen fluid of calves given the two treated diets were anticipated (see Demeyer \& Van Nevel, 1975), but the reverse was observed, suggesting that formaldehyde may not have reduced over-all microbial activity within the rumen, but may have changed the microbial spectrum.

There was no response in microbial protein synthesis to supplementation of formaldehyde treated silage with urea. Rumen degradable N (RDN) may not have been limiting microbial protein synthesis in the rumen of cattle fed the formaldehyde treated silage. On the control diet, RDN amounted to $36 \cdot 1 \mathrm{~g} / \mathrm{kg}$ rumen digested organic matter (RDOM) and microbial $\mathrm{N}$ synthesis, calculated from estimated microbial protein synthesis and the nitrogen to amino acid ratio in microbial material obtained from the rumen of sheep fed silage (Siddons et al. 1979), was calculated to be $23.5 \mathrm{~g} / \mathrm{kg}$ RDOM, a value considerably lower than the optimum value of $30 \mathrm{~g} / \mathrm{kg}$ suggested by the Agricultural Research Council (1980). The application of formaldehyde reduced RDN to $26.5 \mathrm{~g} / \mathrm{kg} \mathrm{RDOM}$, but microbial $\mathrm{N}$ synthesis $(28.4 \mathrm{~g} / \mathrm{kg}$ RDOM) was increased, not reduced, in comparison with the value on diet $\mathrm{C}$. This increase may have been associated with the form of the degraded $N$, the pattern of $\mathbf{N}$ degradation in relation to time and the elevated supply of degraded carbohydrate from the formaldehyde treated diet. The addition of urea increased the supply of RDN to 
Table 8. The rumen degrcidation ( $\mathrm{g} / \mathrm{kg}$ dry matter) of dietary carbohydrate* and nitrogen, the apparent efficiency of capture of degraded $N$ by the microbes and the over-all efficiency of microbial $N$ synthesis of calves given control silage $(C)$, formaldehyde-treated silage $(F)$ and formaldehyde-treated silag,e supplemented with urea $(F U)$

\begin{tabular}{|c|c|c|c|}
\hline Diet... & $\mathrm{C}$ & $\mathbf{F}$ & FU \\
\hline Degraded carbohydrate (DC) & 336 & 440 & 442 \\
\hline Degraded N (DN) & $18 \cdot 4$ & 13.9 & $22 \cdot 6$ \\
\hline DC:DN & $18 \cdot 3$ & $31 \cdot 6$ & $19 \cdot 5$ \\
\hline $\begin{array}{l}\text { Apparent efficiency of } \\
\text { capture of degraded } N(\%)\end{array}$ & 65 & 95 & 55 \\
\hline $\begin{array}{l}\text { Efficiency of microbial } \mathrm{N} \\
\text { synthesis }(\mathrm{g} / \mathrm{kg} \text { rumen } \\
\text { digested organic matter) }\end{array}$ & $23 \cdot 5$ & $28 \cdot 5$ & $25 \cdot 7$ \\
\hline
\end{tabular}

- Dietary carbohydrate, water soluble + cellulose + hemicellulose.

$39.8 \mathrm{~kg}$ RDOM, but either due to the inability of the microbes to incorporate more ammonia or a possible energy limitation in relation to $\mathrm{N}$ supply, microbial $\mathrm{N}$ synthesis $(25.7 \mathrm{~g} \mathrm{~N} / \mathrm{kg} \mathrm{RDOM})$ was not enhanced. An alternative approach to consider differences in microbial $\mathrm{N}$ synthesis is suggested by Thomson \& Beever (1980) who calculated the value for rumen-degradable carbohydrate (DC): degradable $N(D N)$, and used this value to explain differences in the extent and efficiency of microbial $\mathrm{N}$ synthesis on two silage diets compared with fresh grass. Appropriate values for the present study are illustrated in Table 8. The DC:DN value was highest on the formalin diet. This, in turn, was associated with a high efficiency of capture and a high over-all efficiency of synthesis, but for the other two diets DC: DN values were rnuch lower and were associated with lower efficiencies of capture and synthesis.

In an earlier study, Lonsdale et al. (1977) reported a significant response in voluntary food intake when urea was added to a formic-formaldehyde silage compared with the unsupplemented diet. The extra $\mathrm{N}$ supplied from urea may not stimulate net microbial protein synthesis, but the possibility of increased rates of fermentation through an enhanced rate of microbial metabolism cannot be excluded.

On the basis of previously-obtained values for amino acid availability in the small intestine and the efficiency of absorption of energy in the hind-gut (Beever et al. 1977), owing to the absence of information on nutrient flow at the terminal ileum, in the present study it can be estimated that total absorbed energy (TAE) amounted to $9.6,10.9$ and $10.9 \mathrm{MJ} / \mathrm{kg} \mathrm{DM}$ for diets $\mathrm{C}, \mathrm{F}$ and $\mathrm{FU}$, whilst the calculated amounts of absorbed protein were found to be $8 \cdot 1,9.7$ and $9.8 \mathrm{~g} / \mathrm{MJ}$ TAE, indicating a $20 \%$ improvement with the formaldehyde treatment. In relation to the metabolizable protein requirements put forward by the Agricultural Research Cotncil (1980), all three diets would provide sufficient protein for $200 \mathrm{~kg}$ cattle gaining up to $1.25 \mathrm{~kg} / \mathrm{d}$ but for the younger animal, it would appear that the control diet $\mathrm{C}$ would provicle sufficient protein for only $0.25 \mathrm{~kg}$ gain $/ \mathrm{d}$. The protein supply from the two formaldehydis treated diets would be capable of supporting approximately $1 \mathrm{~kg}$ live weight gain/d. These results, based on values given for steers of a large mature breed (Table $4 \cdot 16$ ) are in good agreement with earlier requirements suggested by Egan \& Walker (1975).

In earlier studies of formaldehyde-treated silage fed to sheep, Beever et al. (1977) recorded a depressive effect of formaldehyde on lysine absorption from the small intestine, and suggested the reaction of formaldehyde with the $\mathrm{C}_{5}$-group of lysine as the possible cause. 
The problems of amino acid analysis in acidified solutions containing traces of formaldehyde have been discussed by Hove \& Lohrey (1976) and Gruber \& Mellor (1968), and these phenomena probably reflect the apparently-low lysine values reported by Beever et al. (1977), Barry et al. (1978) and found in the present study. However, if formaldehyde is cleaved from bound protein during transit through the acidic conditions of the abomasum, the possibility of errors in estimating the quantities of lysine entering and being absorbed from the small intestine are likely to be minimized. Thus, it is interesting to record that the size of the increase in lysine flow to the duodenum on the two formaldehyde diets in the present study were much smaller than those recorded for all other amino acids. If these trends are confirmed in subsequent studies, and the possibility of methodology problems eliminated, then the possibility of lysine deficiencies on such diets cannot be ignored.

\section{Conclusions}

This study with young cattle has confirmed earlier findings that formaldehyde treatment of grass before ensiling can, in addition to its effects on silage fermentation, have considerable beneficial consequences on the quantity and nature of the nutrients, principally protein, which becomes available to the host animal for metabolism. Combined acid and aldehyde additive treatment can lead to better utilization by the animal of forages conserved as silage. The responses of young growing cattle and sheep to formaldehyde, and the effects of urea on voluntary feed intake and live weight or carcass weight gain, have been highly variable (Waldo, 1975; Barry, 1976b; Kaiser et al. 1978). The acquisition of the information from this and other similar studies should help in the resolution of some previous as well as future animal production responses.

The authors wish to acknowledge the technical assistance of Messrs R. A. Terry, S. Bowhills, R. T. Evans, R. J. Barnes, R. B. Marshall, R. J. Saynor, Mrs A. S. Keene and Miss R. L. Nixon, the statistical advice of Mr M.S. Dhanoa and the advice and encouragement of Dr D. F. Osbourn. The Grassland Research Institute is financed by the Agricultural Research Council.

\section{REFERENCES}

Agricultural Research Council (1980). The Nutrient Requirements of Ruminants. Farnham Royal: Commonwealth Agricultural Bureaux.

Ash, R. W. (1962). Anim. Prod. 4, 309.

Barry, T. N. (1976a). J. agric Sci., Camb. 86, 379.

Barry, T. N. (1976b). Proc. Nutr. Soc. 35, 221.

Barry, T. N., Mundell, D. C., Wilkins, R. J. \& Beever, D. E. (1978). J. agric. Sci., Camb. $91,717$.

Beever, D. E. (1980). In Forage Conservation in the 80s, [C. Thomas, editor] Occasional Symposium 11, British Grassland Society, p 131.

Beever, D. E., Harrison, D. G., Thomson, D. J., Cammell, S. B. \& Osbourn, D. F. (1974). Br. J. Nutr. $32,99$.

Beever, D. E., Thomson, D. J. \& Cammell, S. B. (1976). J. agric Sci., Camb. 86, 443.

Beever, D. E., Thomson, D. J., Cammell, S. B. \& Harrsion, D. G. (1977). J. agric. Sci., Camb. 88, 61.

Brown, G. F., Armstrong, D. G. \& MacRae, J. C. (1968). Br. vet. J. 124, 78.

Cammell, S. B. (1977). Tech. Rep. Grassld Res. Inst. No. 24, p. 80.

Canaway, R. J. \& Thomson, D. J. (1977). Tech. Rep. Grassld Res. Inst. No. 23, p. 14.

Christian, K. R. \& Coup, M. R. (1954). N.Z. Jl Sci. Tech. A36, 328.

Corbett, J. L., Greenhalgh, J. F. D., McDonald, I. \& Florence, E. (1960). Br. J. Nutr. 14, 289.

Demeyer, D. I. \& Van Nevel, G. J. (1975). In Digestion and Metabolism in the Ruminant, p. 336 [1. W. McDonald and A. C. I. Warner, editors] Armidale: University of New England Publishing Unit.

Dewar, W. A. \& McDonald, P. (1961). J. Sci. Fd Agric. 12, 790.

Egan, A. R. \& Walker, D. J. (1975). Proc. 3rd Wld. Conf. Anim. Prod. p. 552 [R. L. Reid, editor]. Sydney: Sydney University Press.

Elsden, S. R. \& Gibson, Q. H. (1954). Biochem. J. 58, 154.

Ferguson, K. A., Hemsley, J. A. \& Reis, P. J. (1967). Aust. J. Sci. 30, 215. 
Grassland Research Institute (1968). Research Techniques in use at the Grassland Research Institute, Hurley, Bull. 45 Commonw. Bur. Fld. Crops, Farnham Royal: Commonwealth Agricultural Bureaux.

Gruber, H. A. \& Mellor, E. F. 1968). Analyt. Biochem. 26, 180.

Hove, E. L. \& Lohrey, E. (1976). J. Nutr. 106, 382.

Jarrett, I. G. (1948). J. Counc. Sci. Ind. Res. Aust. 21, 311.

Kaiser, A. G., England, P. \& Osbourn, D. F. (1978). Proc. 5th Silage Conf. Ayr, p. 14.

Lonsdale, C. R., Thomas, C. \& Haines, M. J. (1977). J. Br. Grassld. Soc. 32, 171.

MacRae, J. C. \& Armstrong, D. G. (1969). Br. J. Nutr. 23, 15.

Siddons, R. C., Evans, R. T. \& Beever, D. E. (1979). Br. J. Nutr. 42, 535.

Snedecor, G. W. (1956). Statistical Methods, Sth ed. Ames, Iowa: Iowa State College Press.

Terry, R. A. \& Osbourn, D. F'. (1980). In Forage Conservation in the 80's [C. Thomas, editor] Occasional Symposium 11, British Grassland Society, p. 315.

Thomson, D. J. \& Beever, D. E. (1980). In Digestive Physiology and Metabolism in Ruminants, p. 29I [Y. Ruckebusch and P. Thivend, editors]. Lancaster: MTP Press.

Thomson, D. J., Beever, D. E., Latham, M. J., Sharpe, M. E. \& Terry, R. A. (1978). J. agric. Sci., Camb. 91 , 1. Tilley, J. M. A. \& Terry, R. A. (1963). J. Br. Grassld. Soc. 18, 104.

Van Soest, P. J. \& Wine, R. H. (1967). J. Ass. Offic. Analyt. Chem. 50, 50.

Waldo, D. R. (1975). J. Anim. Sci. 41, 424.

Wilkins, R. J., Wilson, R. F. \& Woolford, M. K. (1974). Proc. 5th Gen. Mtg Eur. Grassld Fedn Uppsala, Vaxtodling 29, 197.

Wilkinson, J. M., Wilson, R. F. \& Barry, T. N. (1976). Outl. Agric. 9, 3.

Wilson, R. F. \& Wilkins, R. J. (1972). J. Sci. Fd Agric. 23, 377. 